\author{
Nikola Vladimir \\ E-mail: nikola.vladimir@fsb.hr \\ Ivan Lončar \\ E-mail: lonc1991@gmail.com \\ Ivica Ančić \\ E-mail: ivica.ancic@fssb.hr \\ Ivo Senjanović \\ E-mail: ivo.senjanovic@fsb.hr \\ University of Zagreb, Faculty of Mechanical Engineering and Naval Architecture, \\ I. Lucica 5, 10000 Zagreb, Croatia
}

\title{
Prediction of Noise Performance of Ro-Ro Passenger Ship by the Hybrid Statistical Energy Analysis
}

\begin{abstract}
Noise prediction on board Ro-Ro passenger ship with a capacity of 145 cars and 600 passengers has been performed by means of the hybrid Statistical Energy Analysis (SEA). A general commercial noise analysis software Designer-NOISE is used. Basic issues related to noise on board ships are described, with particular emphasis to regulatory framework. An outline of the used software is presented together with ship technical data and noise source overview. Noise model is described in details and results are presented for selected compartments both without and with sound insulation. In addition to standard noise prediction output, a sensitivity analysis of noise levels with respect to some design parameters (wall thickness, insulation type and thickness, etc.) has been performed. Finally, conclusions on noise performance of a ship are drawn.
\end{abstract}

Keywords: noise prediction, Ro-Ro passenger ship, hybrid SEA, Designer-NOISE, sound insulation

\section{Introduction}

In recent years noise problems on board ships attract much attention of both researchers and engineers. The reasons for that are not only in generally higher installed power in ships, but also originate from increased care for health of crew and passengers. In addition to this, there are significant advances in optimization techniques leading to ship structures with reduced amount of steel (reduced mass) and increased stiffness 
having different noise and vibration patterns, and consequently making the structures generally more sensitive to these problems. Noise problems inherent to ships are subject of investigation for long time, [1], and different possibilities are investigated to reduce noise levels [2]. Noise has negative effects not only on crew and passengers (reduced power of concentration, headache, stress, interference in sleeping pattern, reduced tolerance threshold, increased number of mistakes, reduced working capacity, etc.) [3], [4], [5], but also on the sea life. Nowadays, there are many references to the influence of noise emitted by shipping on marine life, as for instance [6], [7], [8] and actually underwater radiated noise is regularly treated as a kind of pollution. It is reasonable to expect that this problem will be even more important in the future [9]. In addition to this, the airborne noise emissions from ships in port cities are not to be ignored [10].

Nowadays, general trend in marine sector (particularly addressing passenger ships) regarding vibration and noise is treating those phenomena not only within Safety Class, but also Comfort Class and Silent Class, which represent voluntary class notations and are introduced by DNV GL in 2011. Later Lloyd's Register and Bureau Veritas followed this initiative by introducing their definition of comfort level in 2016. All these steps lead to even more restrictive levels of noise and vibration treating them as a matter of not only safety, but improved habitability and ship quality.

Regularly, noise levels on board are measured at ship delivery, and if problems are detected, they should be remedied in order to achieve ship compliance with the prescribed values. In spite of variety of noise abatement methods, elimination of such problems the delivery stage becomes rather expensive, and therefore it is desirable to predict noise levels in the preliminary stage. For that purpose the hybrid Statistical Energy Analysis (SEA) seems to be reasonable choice, due to its simplicity and acceptable accuracy (it is fair to say that in the low-frequency domain the method becomes rather inaccurate).

In this paper, a procedure for noise prediction on board ships is illustrated in case of Ro-Ro passenger vessel. The paper is structured in six sections. In the second one an outline of main noise issues in ships is given and SEA as a used method is elaborated more detailed. Also, special attention is paid to regulatory framework. In the third section a description of the used numerical tool is provided, while fourth section deals with ship particulars and calculation model and setup, respectively. In the fifth section the results are listed together with some useful discussions, and finally concluding remarks are drawn. 


\section{Outline of noise problems on board ships and noise assessment methods}

\subsection{General}

Noise and vibration problems are inherent to all ship structures due to a number of engines and devices needed for ship operation. The main noise sources are in ships are the following: main engine and generator sets, gearboxes, propellers (cavitation effect), exhaust systems with engine room ventilation, auxiliary mechanism such as hydraulic systems, pumps, ventilation and air-conditioning systems, side thrusters, etc., Figure 1. Although noise and vibration problems are usually considered simultaneously, methods for their prediction and measurements are fundamentally different, because they are related to the completely different frequency ranges (noise is in the audible range above $30 \mathrm{~Hz}$ and is evaluated in decibels). The noise consists of two parts which are transmitted through two different transmission paths, Figure 2. In this sense we distinguish airborne and structure borne path, transmitted through the air and structure, respectively. Generally, most of the noise present in ships is actually structure borne noise, while airborne component is present in compartments adjacent to engine room, exhaust system or on decks in the vicinity of chimney [11].

Noise and vibration problems can be resolved by different strategies. Namely, abatement can be achieved at the source, by some path modification, or at the receiver. There is no general rule which of the strategies should be applied, since every problem is a specific case. However, some of the practical solutions in noise abatements in ships are: insulation (especially important is to prevent noise transmission by insulating the engine room), mounting absorption panels, mounting sealing in doors, floating decks, etc. [12].

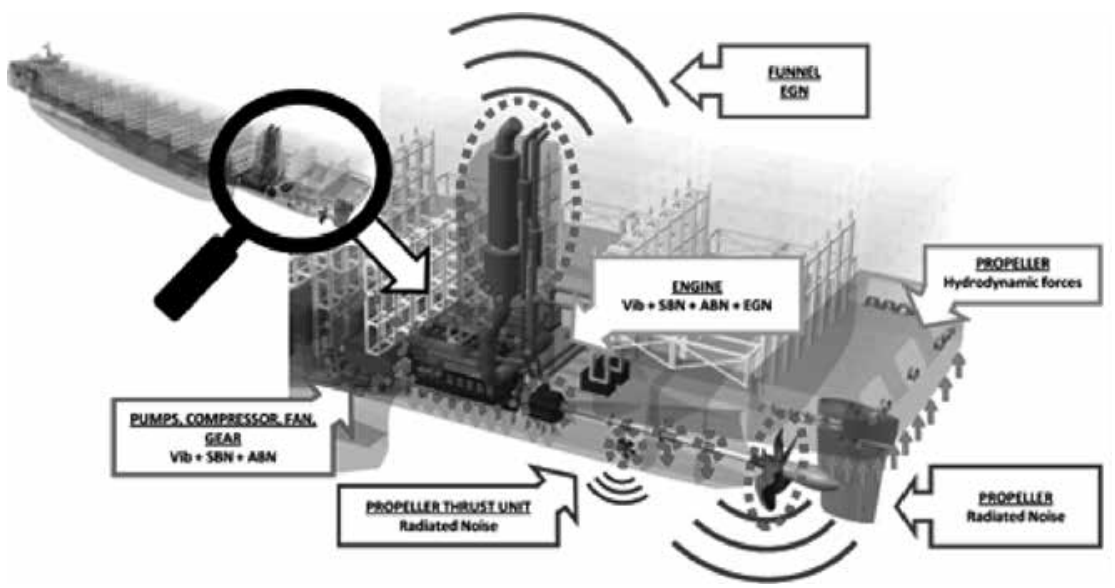

Figure 1: Main noise sources on board [13] 


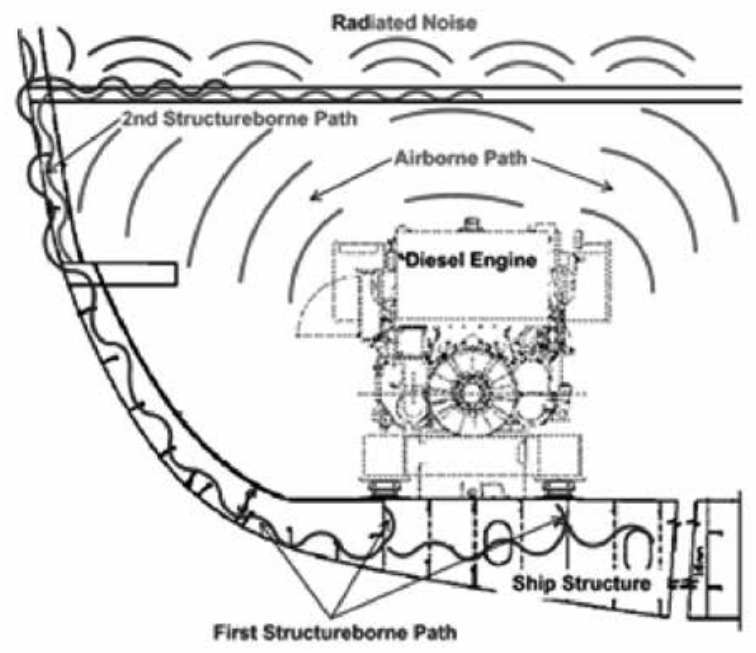

Figure 2: Engine noise with corresponding transmission paths [14]

\subsection{Prescribed noise levels on board}

All involved parties in the marine business (shipyards, classification societies and particularly ship-owners) are dedicated to building of ships with lower noise levels. In November 2012 the Maritime Safety Committee (MSC) of the International Maritime Organization (IMO) adopted the Code on Noise Levels on Board Ships that entered into force $1^{\text {st }}$ of July 2014 [15]. In Table 1 maximum acceptable sound levels are listed according to [15].

Table 1: Maximum acceptable sound levels in ship spaces [15]

\begin{tabular}{|l|c|c|}
\hline \multirow{2}{*}{ Designation of rooms and spaces } & \multicolumn{2}{|c|}{ Ship size } \\
\cline { 2 - 3 } & $\begin{array}{c}\mathbf{1 6 0 0} \text { to } \\
\mathbf{1 0 0 0 0} \text { GT }\end{array}$ & $\geq \mathbf{1 0 0 0 0}$ GT \\
\hline Work spaces & 110 & 110 \\
\hline Machinery spaces & 75 & 75 \\
\hline Machinery control rooms & 85 & 85 \\
\hline Workshops (other than those forming machinery spaces) & 85 & 85 \\
\hline Non-specified work spaces & & \\
\hline Navigation spaces & 65 & 65 \\
\hline Navigation bridge and chartrooms & 70 & 70 \\
\hline Look-out posts, incl. navigating bridge wings and windows & \\
\hline
\end{tabular}




\begin{tabular}{|l|c|c|}
\hline Radio rooms (but not those producing radio signals) & 60 & 60 \\
\hline Radar rooms & 65 & 65 \\
\hline Accommodation spaces & 60 & 55 \\
\hline Cabin and hospitals & 65 & 60 \\
\hline Messrooms & 65 & 60 \\
\hline Recreation rooms & 75 & 75 \\
\hline Open recreation rooms (external areas) & 65 & 60 \\
\hline Offices & 75 & 75 \\
\hline Service spaces & 75 & 75 \\
\hline Galleys, without food processing equipment operating & \\
\hline Serveries and pantries & 90 & 90 \\
\hline Normally unoccupied spaces
\end{tabular}

Beside maximum acceptable sound pressure levels, the Code deals with noise measuring equipment and procedure, noise exposure limits, acoustic insulation between accommodation spaces, hearing protection and warning information as well as with recommendations for noise attenuation methods and simplified procedures for noise exposure determination. Regularly, classification societies directly incorporate the Code in their regulatory framework, as shown for instance in [16].

\subsection{Statistical Energy Analysis (SEA)}

Review of methods for structure borne noise prediction on board ships in presented in [17], where the Finite Element Method (FEM), SEA and the Energy Finite Element Method were examined. In this paper the vibration problem is analysed by SEA, and therefore that method is described more detailed. However, it is to note that general FEM is applicable only to low frequency range and SEA is appropriate for high frequency domain, but for the mid-frequency range there is no fully reliable and robust method today. EFEM is a new approach for simulating high frequency vibration of large-scale structures with a possibility to accurately solve the problem in the midfrequency range. It is based on deriving governing differential equations with respect to energy density variables, and utilizing a FEM for solving them numerically [17]. Its advantage is the potential of modelling the ship structure by relatively coarse mesh of finite elements (preferably the same as for structural analysis).

Application of SEA has long tradition, originating from earlies works of Lyon et al., [18], [19], [20], and after number of improvements and adaptations, there is nowadays number of commercial practical tools for noise predictions relying on SEA, as for instance [21]. The basic idea of the method is to divide a complex structure into a number of coupled subsystems and model the energy flow between them in the transport 
theory manner. Energy balance equations are then set up for these subsystems in terms of their spatially averaged vibration levels, the rate of energy dissipation, the rate of energy exchange and the rate of energy input due to external forces.

If we consider one single subsystem (i), any excitation acting on it can be characterized with resulting power input $P_{i}$ into subsystems. After injecting the power there is amount of vibrational energy $E_{i}$ stored in the system associated with some power loss $P_{i}$ and one can relate them via damping loss factor $\boldsymbol{\eta}_{i}$ :

$$
P_{i i}=\omega \eta_{i} E_{i}
$$

If we assume the steady state, one can write:

$$
P_{i}=P_{i i}
$$

If there is another subsystem $(j)$ coupled to the first one the same power balance can be written for that system also. Because of coupling, subsystems share their vibrational energies, so there is a power flow from subsystem $(i)$ to subsystem $(j)$. From the point of view of subsystem $(i)$ power flow $P_{i j}$ is a power loss and power flow $P_{j i}$ is a power gain. The same is with subsystem $(j)$.

$$
P_{i j}=\omega \eta_{i j} E_{i}
$$

In work of Weryk [11], an example of four coupled subsystems is presented, Figure 3 , showing only power input to subsystem 1 . That power input is equal to the sum power losses for whole system minus the power gains coming from the subsystems 2 and 3.

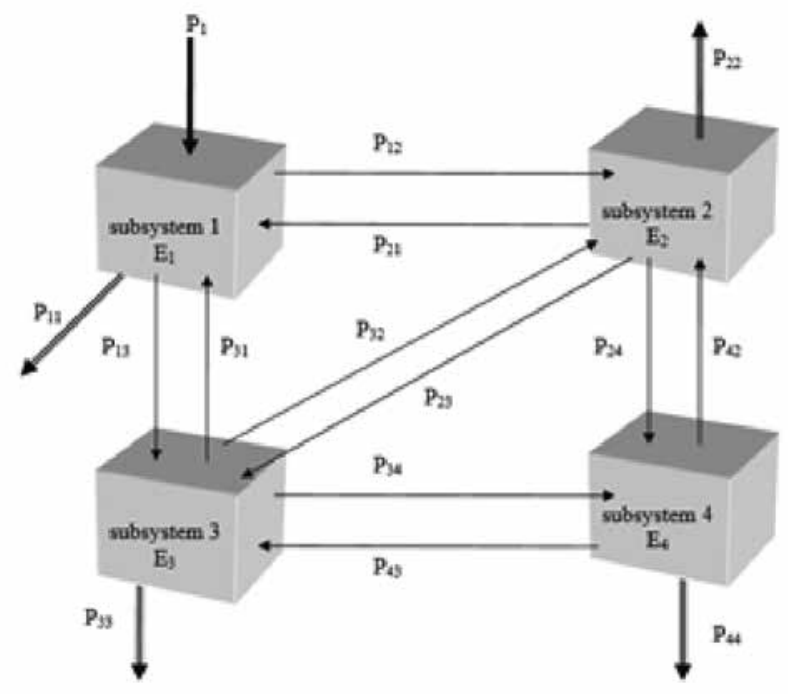

Figure 3: Four coupled subsystems [11] 
According to [11] the power balances are written in the following form:

$$
\begin{gathered}
P_{1}=P_{11}+P_{12}+P_{13}-P_{21}-P_{31} \\
0=P_{22}+P_{21}+P_{23}+P_{24}-P_{12}-P_{32}-P_{42} \\
0=P_{33}+P_{31}+P_{32}+P_{34}-P_{13}-P_{23}-P_{43} \\
0=P_{44}+P_{42}+P_{43}-P_{24}-P_{34}
\end{gathered}
$$

Bearing in mind equations (1) and (3), one can substitute above equations into damping and coupling loss factors and vibrational energy, that gives:

$$
\omega\left(\begin{array}{cccc}
\eta_{11} & -\eta_{21} & -\eta_{31} & -\eta_{41} \\
-\eta_{12} & \eta_{22} & -\eta_{32} & -\eta_{42} \\
-\eta_{13} & -\eta_{23} & \eta_{33} & -\eta_{43} \\
-\eta_{14} & -\eta_{24} & -\eta_{34} & \eta_{44}
\end{array}\right) \cdot\left(\begin{array}{c}
E_{1} \\
E_{2} \\
E_{3} \\
E_{4}
\end{array}\right)=\left(\begin{array}{c}
P_{1} \\
0 \\
0 \\
0
\end{array}\right)
$$

The diagonal elements of the loss factor matrix are called the total loss factors as they are the sum of all coupling loss factors associated with power losses for the given subsystem, [11]:

$$
\eta_{i i}=\eta_{i}+\sum_{j, j \neq i} \eta_{i j}
$$

The principle difference between the EFEM and SEA is the energy balance formulation for each element. For SEA it is assumed that energy density does not depend on coordinates inside an element. Physically this means that there is a diffusive field for each element. Energy balance in this case is expressed mathematically as a linear algebraic equation that equates the energy going in and out of each element. Energy density is unknown in this equation. The number of equations is equal to number of elements. The combination of all equations produces a system of the linear algebraic equations, which has one solution for each set of energy inputs. For EFEM, energy balance is formulated for differential parts of an element. Mathematically, it leads to a second order partial differential equation relative to energy density for each connected element. An analytical solution for partial differential equation is not practical, while numerical methods provide a feasible solution [11]. 


\section{Designer-NOISE}

Designer-NOISE is a software developed for quick and accurate predictions of noise levels on surface ships and other stiffened plate structures. As claimed by the developers, octave-band and overall A-weighted noise levels are calculated based on sound propagation from machinery, propeller, and wave slap sources via airborne and structure borne paths [21].

The software uses a 3-D Graphical User Interface (GUI) for model creation and definition of model parameters, Figure 4.

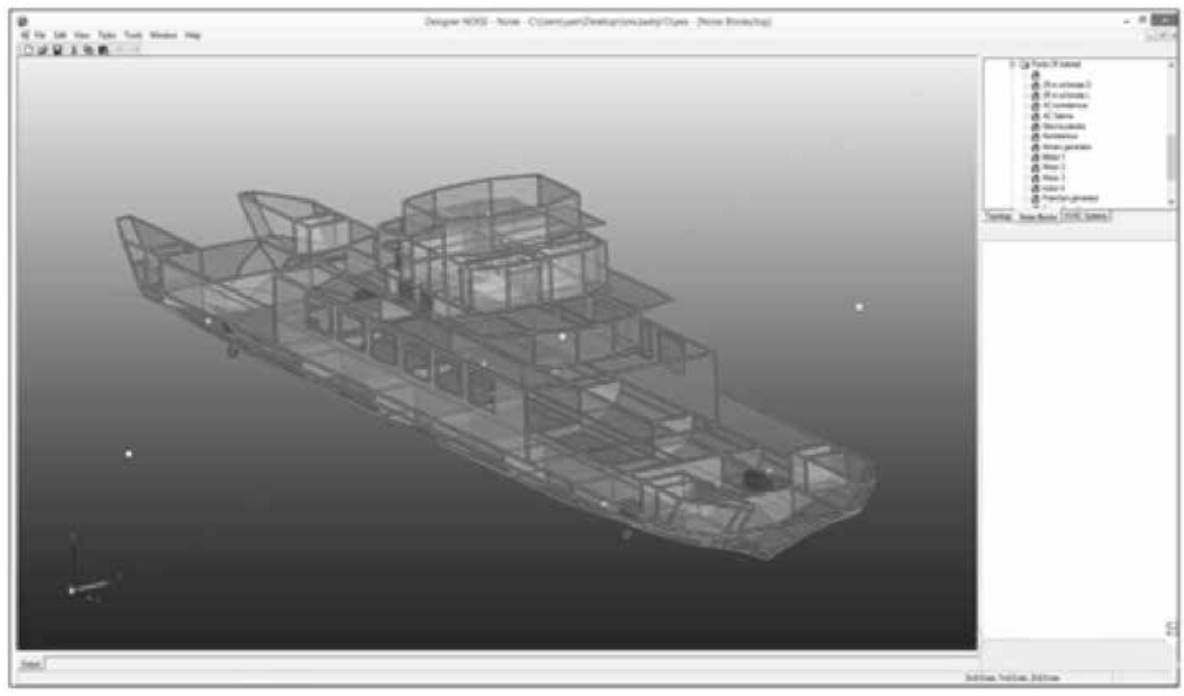

Figure 4: Designer-NOISE graphical user interface

The core solver uses a hybrid SEA approach to predict spreading of vibration throughout the vessel. Architectural acoustic methods are used to predict the spreading of airborne noise. Nearly any machinery source can be modeled, ranging from propulsion engines to fan coil units, and input of calculation data is done in very simple manner, Figure 5. HVAC analyses can also be performed, and the resulting noise levels can be combined with machinery noise results. Most importantly, the causes of noise in any compartment can be evaluated, and various treatment options can be explored, including resiliently mounting equipment, adding absorptive insulation and/or damping materials, etc. By using the software the treatments can be quickly optimized to meet acoustic goals while minimizing impacts to space, weight, and cost [21]. The claimed prediction accuracy is within $3 \mathrm{~dB}$ for A-weighted noise levels. 


\begin{tabular}{|c|c|c|}
\hline \multirow[t]{8}{*}{4} & \multicolumn{2}{|l|}{ Ideribly } \\
\hline & Harse & Aoter I \\
\hline & Source id & 17 \\
\hline & 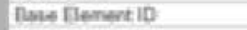 & 30 \\
\hline & Conpertunert it & 63 \\
\hline & Is Aective? & Falson \\
\hline & Source Type & Machinem \\
\hline & Libror Sourtet & Nures \\
\hline \multicolumn{3}{|c|}{ - Permetern-Coondinibe Syakm } \\
\hline$\Rightarrow$ & Foundation Dingen & $(24555,5447,1.700) \mathrm{m}$ \\
\hline$>$ & Leat $X$-avis & $(3,000,0009.0000) \mathrm{n}$ \\
\hline \multirow[t]{2}{*}{$>$} & Local 2-ines & S6000 0000.1000 in \\
\hline & Rotabon Angle & 00 \\
\hline \multirow[t]{5}{*}{ a } & Peremelos -Move & \\
\hline & Source Lerght & $2456 \mathrm{~m}$ \\
\hline & Source intaty & $1200 \mathrm{~m}$ \\
\hline & Swext Heigt & $1200 \mathrm{~m}$ \\
\hline & Sovicto A & t. \\
\hline$>$ & Source Hoine Levels & $111,115,114,162,102,162,50,26,7$ \\
\hline$\Rightarrow$ & Antorne Sowce Ottset & $100.00 .001 \mathrm{man}$ \\
\hline \multirow[t]{2}{*}{$a$} & Peineters = Wordion & \\
\hline & Man & 4606 torne \\
\hline \multirow[t]{6}{*}{$\rightarrow$} & Spunce Viteration Levels & $111.119,114.102 .100,102.90,00,7$ \\
\hline & Fevindoliten Lengh & $2450 \mathrm{~m}$ \\
\hline & foundsbon what & $1.200 \mathrm{~m}$ \\
\hline & Foundalion RD & MoDen \\
\hline & Sowred Dats Type & Nownther \\
\hline & Mounting Type & Hond \\
\hline \multirow[t]{5}{*}{$t$} & Sexarce Plenent & \\
\hline & Type el Bute Berient & Siardasdidin \\
\hline & Large Fanel Lergth & $3600 \mathrm{~m}$ \\
\hline & Lange Fanel Whath. & $2000 \mathrm{~m}$ \\
\hline & 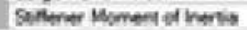 & $\operatorname{comap} 0 \mathrm{em}$ \\
\hline
\end{tabular}

Figure 5: Example of noise data definition

\section{Ship particulars, analysis model and calculation setup}

\subsection{Ship particulars}

The considered ship is a Ro-Ro passenger vessel, that has been built several years ago in a Croatian shipyard within family of four sister ships, Figure 6. Ship general arrangement is shown in Figure 7.

The ship main particulars are listed below:
Length overall:
$99.8 \mathrm{~m}$
Length between perpendiculars:
$89.1 \mathrm{~m}$
Breadth:
$17.5 \mathrm{~m}$
Draught:
$2.4 \mathrm{~m}$
Deadweight at max. draught:
$950 \mathrm{t}$
Design speed:
$12.5 \mathrm{kn}$

The vessel is built as double ended ferry and is classified by Croatian Register of Shipping. It has four Volvo Penta main engines with an output of $450 \mathrm{~kW}$ each, and is equipped with four FPP Schottel thrusters with possibility of rotation 360 deg around vertical axis by means of hydraulic. More data on the vessel can be found in [23]. 
The noise induced by the following noise sources is taken into account:

- Main engines,

- Auxiliary gensets,

- HVAC system

- Propellers.

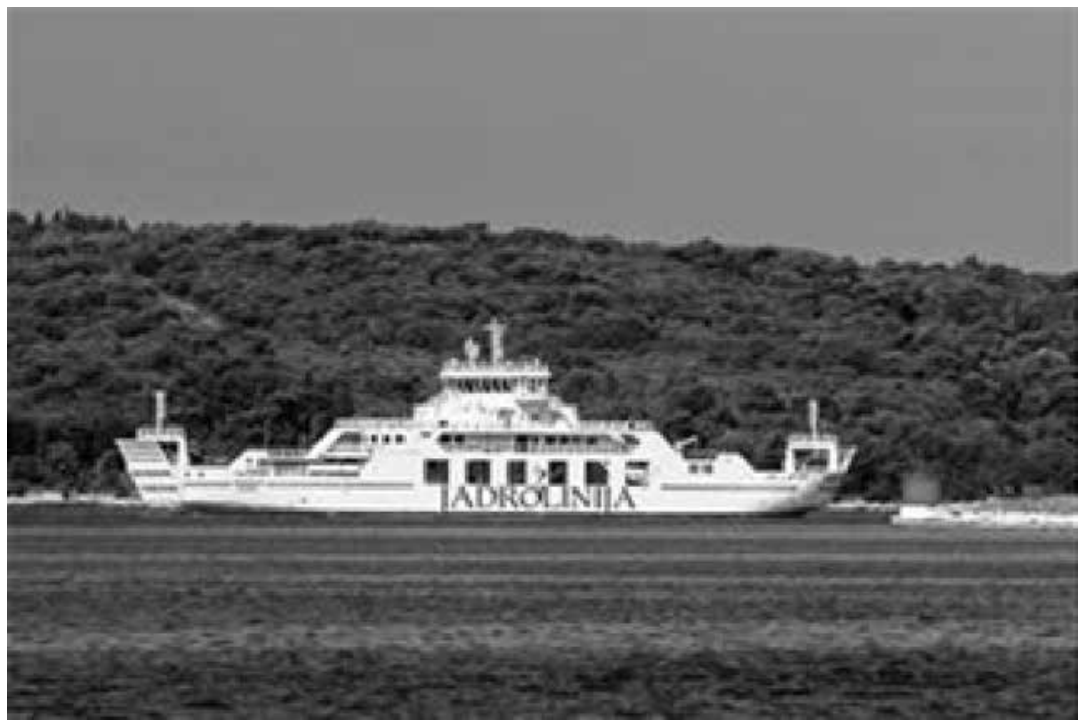

Figure 6: Analysed Ro-Ro passenger ship in operation [22]

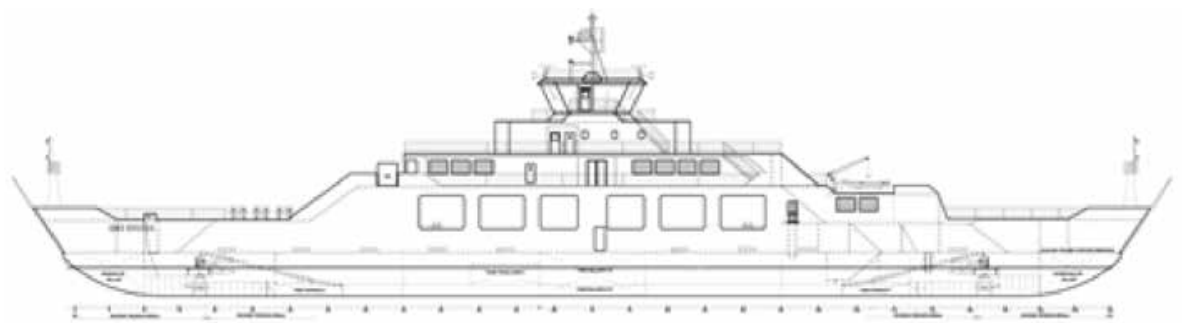

Figure 7: General arrangement of the analysed Ro-Ro passenger ship

\subsection{Analysis model and calculation setup}

The generated analysis model is shown in Figures 8 and 9. In total, the model consists of 89 compartments and 632 elements. The compartments for which the noise levels are calculated are called compartments of interest (COI). All compartments of the generated model are actually visible within software GUI presentation (see Figure 4). 


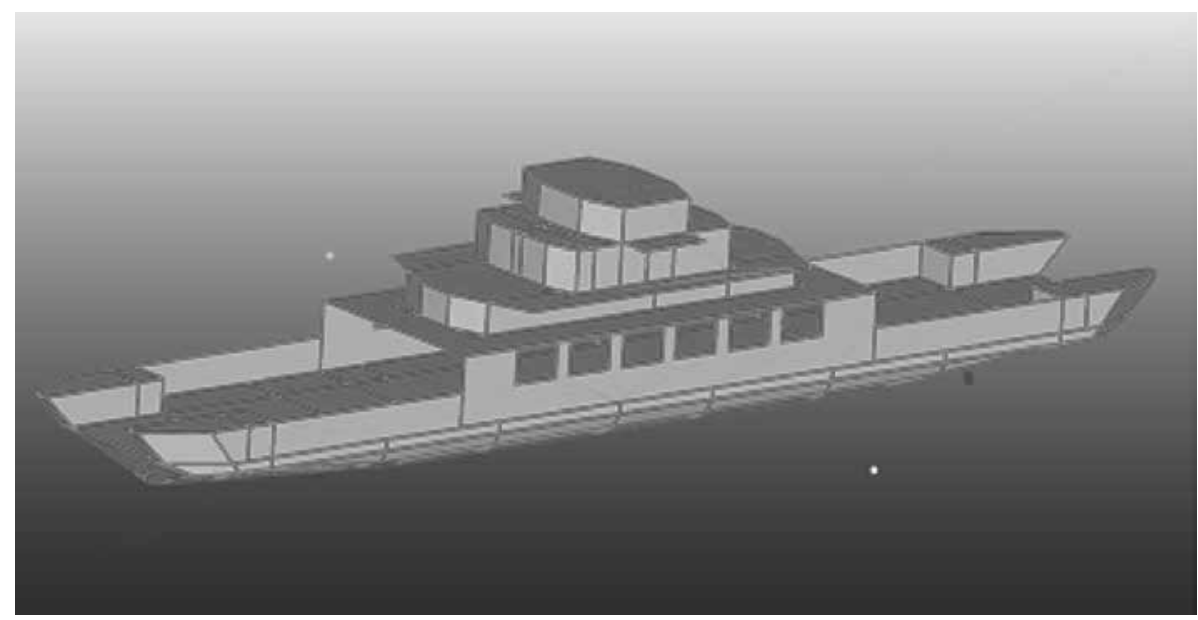

Figure 8: Model of the analysed Ro-Ro ship-side view

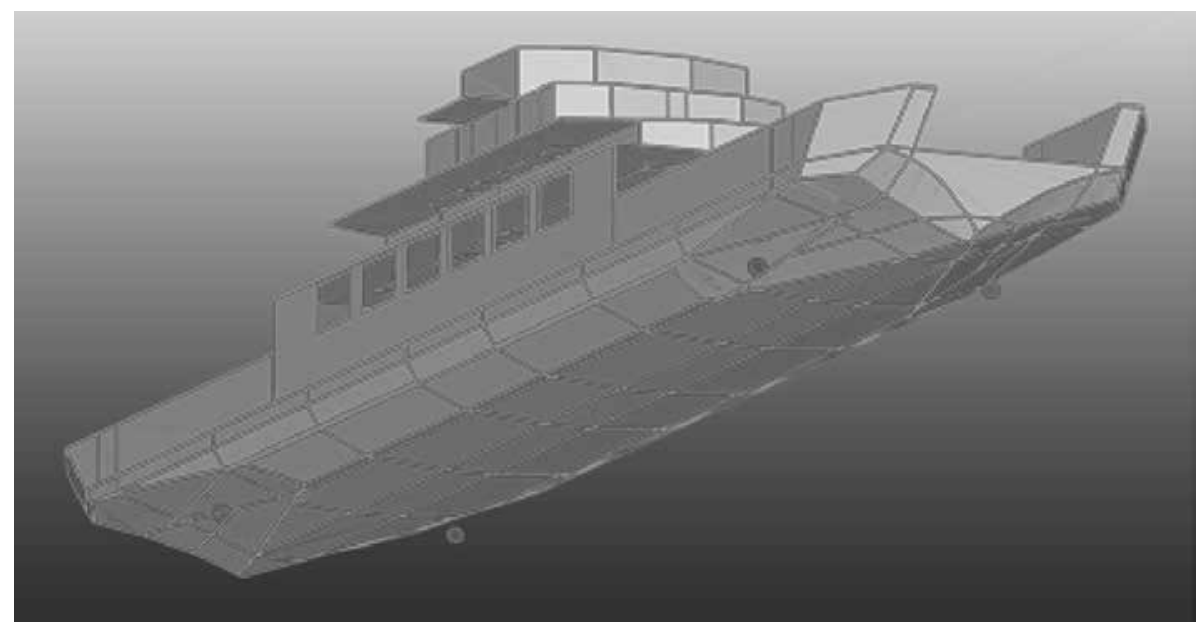

Figure 9: Model of the analysed Ro-Ro ship-bottom view

Regarding the noise sources, it is fair to say that not all data were known to the authors. Since the aim of the paper is to illustrate the noise assessment procedure, but not the noise analysis of the ship itself, unknown noise levels for some devices were taken based on the realistic data available for the devices with nearly same working characteristics. Noise levels of the considered sources that were taken in the calculation are listed in Table 2.

As indicated above, the analysis was performed in two steps. In the first one, ship without any insulation is considered, while in the second one insulation treatments at the locations with higher noise levels is applied, as for example the one shown in Figure 
10. Also, in order to reduce both structure borne paths and radiated noise, engine room walls were insulated, Figure 11.

Table 2: Noise levels for considered sources $d B(A)$

\begin{tabular}{|c|c|c|c|c|c|c|c|c|c|}
\hline Frequency $(\mathrm{Hz})$ & 31.5 & 63 & 125 & 250 & 500 & 1000 & 2000 & 4000 & 8000 \\
\hline Main engine & 110 & 110 & 114 & 102 & 102 & 102 & 90 & 80 & 78 \\
\hline Gen set & 108 & 112 & 112 & 104 & 104 & 102 & 92 & 80 & 78 \\
\hline AC Unit & 90 & 91 & 91 & 93 & 91 & 84 & 78 & 74 & 72 \\
\hline Ventilator & 91 & 91 & 89 & 81 & 71 & 71 & 65 & 63 & 61 \\
\hline
\end{tabular}

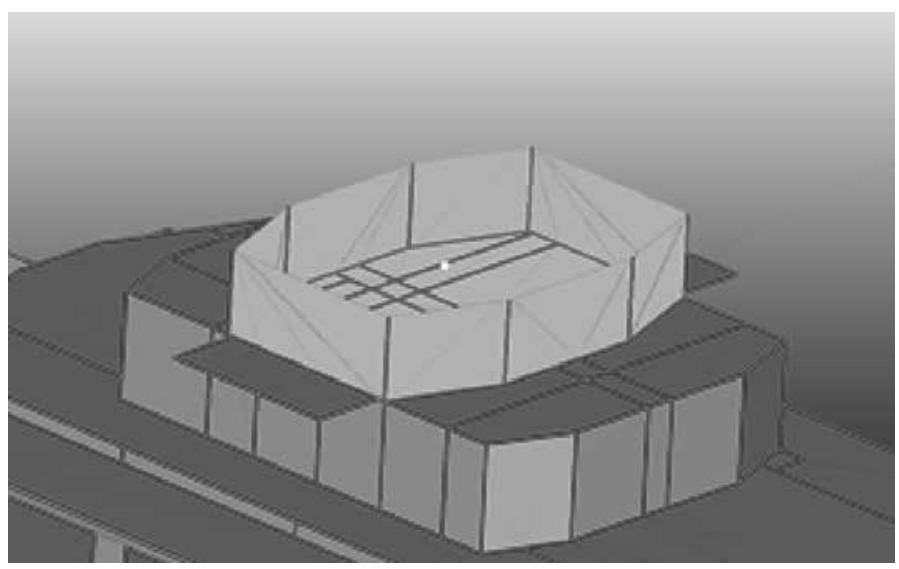

Figure 10: Insulated walls of the wheelhouse

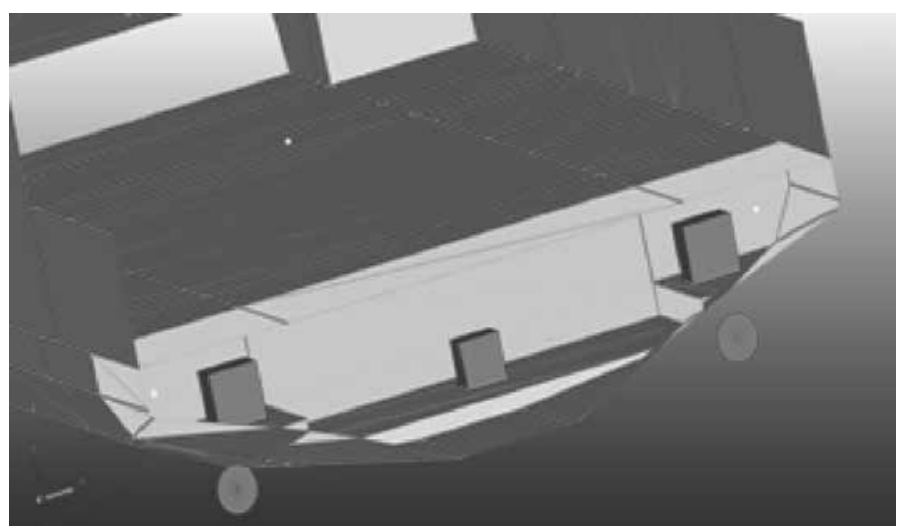

Figure 11: Engine room with noise sources and sound insulation 
Apart from usual noise calculations, a space in the ship structure (Room 1, Figure 12) is selected to perform noise level sensitivity analysis with respect to wall thickness and insulation type and thickness, respectively. Only software default materials were tested, as shown in Table 3.

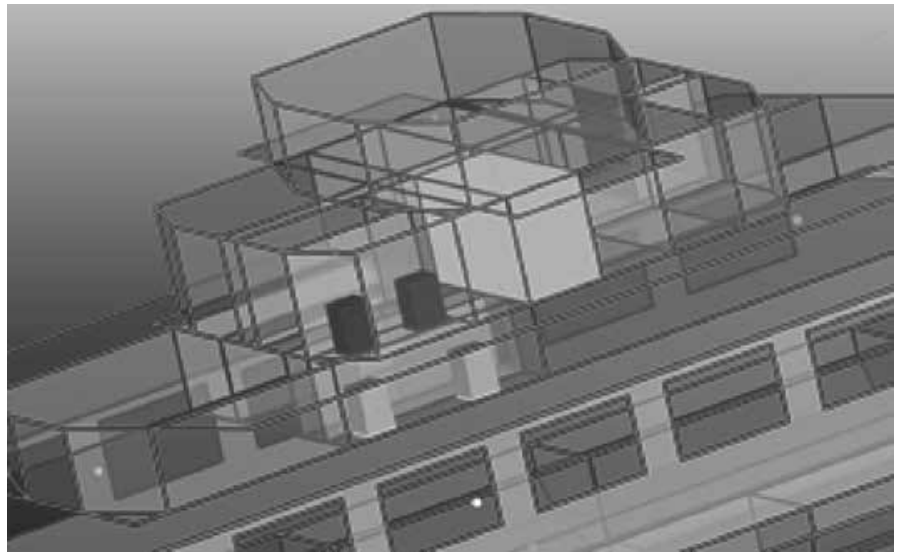

Figure 12: Room 1 in the ship structure

\begin{tabular}{|c|c|c|c|c|c|c|c|c|c|}
\hline Material & Meterial Thidonesa (mm) & Description & 125Ht & $250 \mathrm{~Hz}$ & $560 \mathrm{Ft}$ & $1000 \mathrm{~Hz}$ & $2000 \mathrm{Hr}$ & $6000 \mathrm{~Hz}$ & e $8000 \mathrm{~Hz}$ \\
\hline Mat-1-722Typet & 25 & Tikerglass Bourd w/ sow perforated cloth reinfoeced Mylaz & a.1s & 0.7 & ass & as & a.n & ast & aen \\
\hline Mat-1-342TypeI & so & Fîterglass Boand w/ noesperficrated cloch reinfoeced Myle & a.6 & 1.1 & OS4 & a.46 & a.2s & a.3 & a.12 \\
\hline MEt1-A-20054 & 23 & Tibenglan w/ waftlebourd and perforated fberglas facing & a.s6 & 0.93 & 1.18 & 1.11 & a.96 & 0.57 & ass \\
\hline Math-2003 Type is & 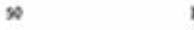 & Tiberglass w/ non-perforated Tuffikin facing & 0.52 & 1 & 1 & ans & Q.36 & ass & a.s \\
\hline DoD:G46es Iypel & is & Nen faced Polyimide foum & a.ts & 027 & Q.65 & 1 & Q.4.4 & as & ass \\
\hline DCO-24tis\$ Type1 & $\boldsymbol{*}$ & Noe-faced Polyinide form & 0.23 & Q.5s & 1 & a.8 & ats & ans & ast \\
\hline DCO-1246ss Typell & 25 & Polyimide foum $w /$ perborsted fiberglass abeh fucing & 0.09 & ost & $0.8 \%$ & ast & ass & ass & an \\
\hline Deosc4tes Iypell & so & Poyyimide fourn w/ perborated fiterglust cloch facing & 0.27 & 0.81 & 1 & $a n$ & 1 & ass & 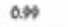 \\
\hline
\end{tabular}

Table 3: Properties of absorptive materials (Sabine coefficients)

\section{Results}

After performing the analysis for the non-insulated ship case, excessive noise levels were obtained at accommodation deck while in cabins marginal values are noticed. The results for selected compartments of interest are summarized in Table 4 . As an insulation material, polyamide foam with $50 \mathrm{~mm}$ thickness, Table 3 , is used and noise levels are significantly decreased. 
Table 4: Predicted noise levels in compartments of interest $d B(A)$

\begin{tabular}{|c|c|c|c|}
\hline Space & $\begin{array}{c}\text { Without } \\
\text { insulation }\end{array}$ & $\begin{array}{c}\text { With } \\
\text { insulation }\end{array}$ & $\begin{array}{c}\text { Prescribed } \\
\text { noise levels }\end{array}$ \\
\hline Wheelhouse & 56 & 49 & 65 \\
\hline Accommodation deck & 70 & 57 & 65 \\
\hline Cabin & 60 & 51 & 60 \\
\hline
\end{tabular}

Typical software output is shown for accommodation deck, Figures 13 and 14 , with and without insulation respectively.
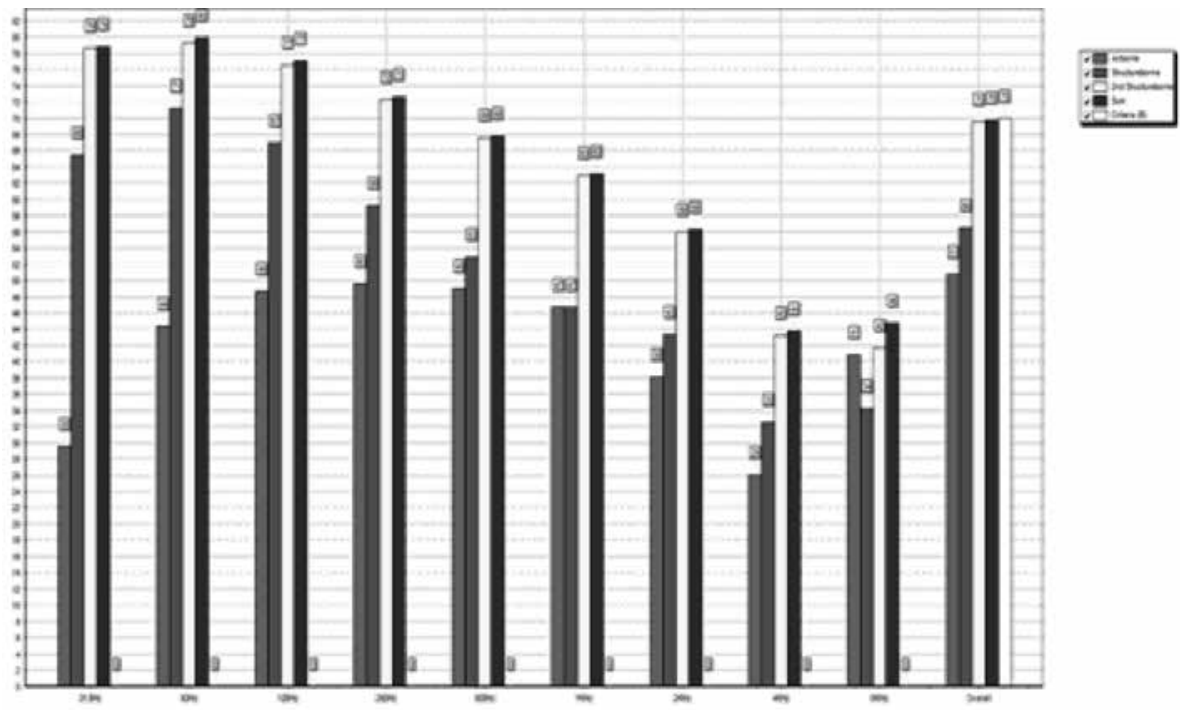

Figure 13: Noise levels at accommodation deck without insulation 

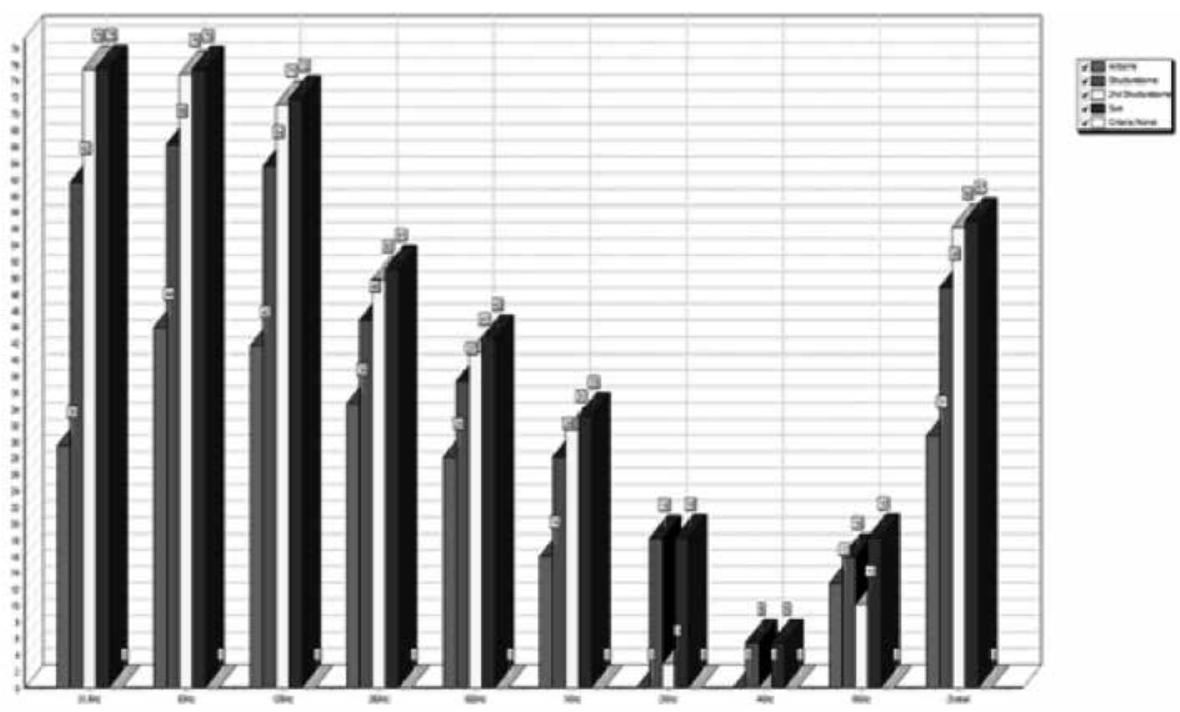

Figure 14: Noise levels at accommodation deck with insulation

Sensitivity analysis regarding the insulation type and thickness showed that noise levels in Room 1 can be decreased up to $15 \mathrm{~dB}(\mathrm{~A})$. Results for different wall thickness are shown in Table 5 and are practically independent on the thickness of plating.

Table 5: Influence of wall thickness on noise levels $d B(A)$

\begin{tabular}{|l|c|c|c|c|}
\hline Thickness & $6 \mathrm{~mm}$ & $10 \mathrm{~mm}$ & $14 \mathrm{~mm}$ & $18 \mathrm{~mm}$ \\
\hline First structure borne path & 34 & 34 & 34 & 34 \\
\hline Second structure borne path & 44 & 44 & 43 & 43 \\
\hline Total & 45 & 44 & 43 & 43 \\
\hline
\end{tabular}

\section{Conclusions}

In this paper, a procedure for noise prediction on board ships by the hybrid Statistical Energy Analysis is illustrated, taking Ro-Ro passenger ship as a test case. The prediction has been performed by means of commercial software Designer-NOISE. General information on noise problems in ships are outlined and concept of SEA is described.

In the first step, the ship without insulation is analysed, and later the case with insulation is considered. It is confirmed that after insulation installation the obtained noise levels are below prescribed values, which is in line with the fact that ship has been built several years ago, and that it operates with no noise problems claimed. Also, influence of wall thickness as well as insulation type and thickness is analysed 
for a selected compartment. As expected, the results show that wall thickness has no significant influence on the total noise levels, while in the case of insulation the noise levels are highly dependent both on material absorptive characteristics and thickness.

\section{References}

1. WILSON, W.K.: ,, The noise problem on board ship “, Naval Engineers Journal, Vol. 68, No. 3, 1956, pp. 506-514.

2. TURNER, A.E.: ,, The use of damping materials for noise reduction on a passenger ship “, Journal of Sound and Vibration, Vol. 10, No. 2, 1969, pp. 189-197.

3. TAMURA, Y., KAWADA, T., SASAZAWA, Y.: , Effects of ship noise on sleep “, Journal of Sound and Vibration, Vol. 205, No. 4, 1997, pp. 417-425.

4. KURT, R.E., KHALID, H., TURAN, O., HOUBEN, M., BOS, J., HELVACIOGLU, I.H.: „, Towards human-oriented norms: Considering the effects of noise exposure on board ships ", Ocean Engineering, Vol. 120, 2016, pp. 101-107.

5. BORELli, D., GAGGERO, T., RIZZUTO, E., SCHENONE, C.: „,Analysis of noise on board a ship during navigation and manoeuvres ", Ocean Engineering, Vol. 105, 2015, pp. 256-269.

6. BADINO, A., BORELli, D., GAGGERO, T., RIZZUTO, E., SCHENONE, C.: „, Noise emitted from ships: Impact inside and outside the vessels ", Procedia - Social and Behavioural Sciences, Vol. 48, 2012, pp. 868-879.

7. MERCHANT, N.D., PIROTTA, E., BARTON, T.R., THOMPSON, P.M.: „, Monitoring ship noise to assess the impact of coastal developments on marine mammals ", Marine Pollution Bulletin, Vol. 78, No. 1-2, 2014, pp. 85-95.

8. WILLIAMS, R., ERBE, C., ASHE, E., BEERMAN, A., SMITH, J.: „, Severity of killer whale behavioural responses to ship noise: A dose-response study", Marine Pollution Bulletin, Vol. 79, No. 1-2, 2014, pp. 254-260.

9. KAPLAN, M.B., SOLOMON, S.: „A coming boom in commercial shipping? The potential for rapid growth of noise from commercial ships by 2030“", Marine Policy, Vol. 73, 2016, pp. 119-121.

10. BADINO, A., BORELLI, D., GAGGERO, T., RIZZUTO, E., SCHENONE, C.: „,Airborne noise emissions from ships: Experimental characterization of the source and propagation over land", Applied Acoustics, Vol. 104, 2016, pp. 158-171.

11. WERYK, M.: ,, Ship on board noise propagation analysis methods“, Hydroacoustics, Vol. 15, 2012, pp. 187-194.

12. „How to handle noise and vibration in ships “, The Danish Fishermen's Occupational Health Counsil, $2^{\text {nd }}$ Ed., Esbjerg, 2000.

13. TUDOR, H.: „Techno-economic assessment of new marine engine development with high noise and vibration performance", M.Sc. Thesis, University of Zagreb, Faculty of Mechanical Engineering and Naval Architecture, 2017.

14. http://noise-control.com/Designer_Noise_Help/, (access on: $2^{\text {nd }}$ of August 2017).

15. IMO: ,,Resolution MSC.337(91)-Adoption of the Code on Noise Levels on board ships “, 2012.

16. CROATIAN REGISTER OF SHIPPING: „,Rules for Technical Supervision of Sea-Going Ships, Part 20 - Protection at Work and Crew Accommodation ", 2015.

17. PARUNOV, J., PESTELLI, C., RUDAN, S., HADŽIĆ, N., SENJANOVIĆ, I.: „,Review of methods for structure born noise prediction on ships “, Brodogradnja, Vol. 63, No. 2, 2012, pp. 134-139.

18. LYON, R.H., SCHARTON, T.D.: „, Vibrational energy transmission in three element structure“, Journal of Acoustical Society of America, Vol. 38, No. 2, 1965, pp. 253-261.

19. LYON, R.H.: ,, What good is Statistical Energy Analysis anyway? “, Shock and Vibration Digest, Vol. 3, No. 6, 1970, pp. 2-10.

20. LYON, R.H.: ,, Statistical Energy Analysis of dynamical systems “, 1975, The MIT Press, London.

21. http://www.noise-control.com/designernoise.php, (access on: $5^{\text {th }}$ of August 2017).

22. http://www.jadrolinija.hr/, (access on: $3^{\text {rd }}$ of August 2017).

23. https:/www.uljanik.hr/hr/uljanik-grupa/uljanik-d-d/nasi-proizvodi?id=354\#paragraph17, (access on: $5^{\text {th }}$ of August 2017). 
Nikola Vladimir, Ivan Lončar, Ivica Ančić, Ivo Senjanović

\section{Prognoza akustičkih značajki ro-ro putničkog broda hibridnom statističkom analizom energije}

\section{Sažetak}

Ovaj rad vezan je za prognozu buke na Ro-Ro putničkom brodu kapaciteta 145 automobila i 600 putnika hibridnom statističkom analizom energije. Korišten je opći komercijalni programski paket za analizu buke Designer-NOISE. Opisani su osnovni problemi vezani za buku na brodovima, s naglaskom na zakonsku regulativu koju propisuju regulatorne institucije. Dan je kratki prikaz korištenog programskog paketa, kao i osnovni tehnički podaci broda i samih izvora buke. Generirani model broda je detaljno opisan, a rezultati analize su prikazani za odabrane odjeljke broda bez zvučne izolacije i s njom. Uz standardne rezultate prognoze buke, dana je i analiza senzitivnosti razina buke $u$ jednom odjeljku u odnosu na određene projektne parametre (debljinu stijenke, tip i debljinu izolacije, itd.). Zaključno, dana je ocjena akustičke podobnosti broda.

Ključne riječi: prognoza buke, Ro-Ro putnički brod, hibridna statistička analiza energije, DesignerNOISE, zvučna izolacija 
